\title{
Customers' Retention in Micro Finance Banks: An Analysis of Drivers and Inhibitors
}

\author{
Nkanikpo I. Ibok ${ }^{1} \&$ Paul O. Udofot ${ }^{2}$ \\ ${ }^{1}$ Department of Marketing, University of Uyo, Uyo, Nigeria \\ ${ }^{2}$ Department of Business Management, University of Uyo, Uyo, Nigeria \\ Correspondence: Paul O. Udofot, Department of Business Management, University of Uyo, Uyo, Nigeria. E-mail: \\ podofot@yahoo.com
}

Received: July 18, 2012 Accepted: August 7, 2012 Online Published: September 10, 2012

doi:10.5539/ijms.v4n5p74 URL: http://dx.doi.org/10.5539/ijms.v4n5p74

\begin{abstract}
The general purpose of this study was to examine those service characteristics that impact on customers' etention within the context of micro finance institutions in Akwa Ibom State of Nigeria. Regression model was used in analyzing the data received from 90 respondents patronizing 13 licensed micro finance banks in the State. Simple percentages were used to analyse the demographic characteristics of micro- finance customers tabulated in a bi-variant frequency table. The paper identifies a number of drivers and inhibitors of retention behaviours and underscored the need for their proper understanding. Pro-active and reactive retention measures were recommended as necessary conditions for improving retention and general business performance among micro finance banks.
\end{abstract}

Keywords: micro finance banks, customer characteristics, customer retention, customer inhibitors

\section{Introduction}

Customer retention refers to customer's stated continuation of a business relationship with the firm (Timothy, Bruce, Larzan \& Jao, 2007). Unlike the conventional commercial banking sector in Nigeria which is matured and sophisticated, the micro-finance institutions particularly in Akwa Ibom State is presently fragmented. Small-scale retail banking dominates the sector with low or poor customers loyalty and technological innovations. Despite its massive appeal in recent years, the sector has not expanded structurally due to lack of customers' confidence. Also, there is lack of documentation of academic analyses of the performance of the sector. These have caused negative perceptions about the sector. The combination of academic indifference and loss of customers' confidence suggest that there is a dearth of data on published research about the sector in Nigeria. Therefore, based on such low academic involvement in the sector and lopsided customers' confidence, customer retention has become a major challenge to micro finance institutions. It is therefore of utmost importance that micro- finance institutions in Akwa Ibom State do understand and appreciate those service attributes that appeal to their customers in order to satisfy them and ultimately retain them for continuous business.

The sheer absence of studies about the sector suggests that this would have profound effect in the future on customer retention. However, there is less evidence to suggest that customers' retention strategies are being implemented by most micro-finance institutions particularly in a developing economy like Nigeria. This study therefore attempts to address this need by providing answers to the following research questions:

(a) What are the demographic characteristics of micro finance bank customers in Akwa Ibom State?

(b) What are the key service drivers that can lead to retention as practiced by the micro finance banks?

\subsection{Objectives of the Study}

The major objective of this study is to identify those factors that are most likely to drive customers' retention among micro finance banks in Akwa Ibom State. The specific objectives are to:

(i) Describe the demographic characteristics of micro finance bank customers in the study area.

(ii) Examine service characteristics affecting customers' retention in the study area. 


\subsection{Justification of the Study}

A study of customers' loyalty to firms and its impact on retention behavior of customers is very important in the micro finance institutions for a number of reasons; namely; micro finance banks in Nigeria are relatively very young and are passing through developmental challenges and there is little or no data available on the sector, particularly in the field of consumer behavior. Secondly, a thorough understanding of consumers' motivation to patronize the banks is very essential and needs to be examined in the context of micro finance banks. Thirdly, it is hoped that this study will help micro finance managers to formulate more coherent and targeted strategies aimed at attracting, growing and retaining customers. Fourthly, this study is also aimed at contributing to a better understanding and appreciation of consumers' demographic characteristics that would enable micro finance managers to be more effective in targeting, positioning and segmenting their markets. Fifthly, it is believed that the findings of this research will go a long way in helping managers of organizations rethink their critical success factors and incorporate them into strategic planning. Future researchers in this field might find the study useful as it may represent an initial field survey for subsequent studies. This research is also intended to provoke scholarly enquiries and discussions in consumer behavior in the micro finance banks.

\section{Literature Review}

The need for sustainable corporate performance has been well articulated and documented in recent years (Robson, 2002; Palmer, 2002; Reichheld and Sasser, 1990; Neith 2001; Webster 1992). Customers satisfaction has traditionally been recognized as a major determinant of continued loyalty and long term responsive behavior (Oliver, 1980; Fornell, 1992). Several studies including (Anderson, Fornell and Lehmann, 1994; Jones and Earl, 1995;Koy, 2003; Reichheld and Kenny, 1990) have given a direct and quantifiable relationship between customers satisfaction and retention on the one hand and between customers retention and a firms performance on the other hand. Also, the link between customer satisfaction and economic performance in general has been pointed out by (Anderson and Sullivan, 1998).

Customer satisfaction is a measure of how a firm's product or services is able to meet or surpass customer expectation. Thus, in a competitive market like the banking industry, it consists of the firm crafting holistic strategies in order to keep the customers happy. Several scholars have shown a significant relationship between customer satisfaction and retention (Jones and Earl, 1995; Oyenihi and Abiodun, 2008; Timothy, Larzan and Jao, 2007). Undoubtedly, the micro finance banks are gradually expanding both in scope and content, and these calls for re-strategisation not only in beating competition but also in creating more values for the customers. This therefore requires the building of strong business customer relationships and sustained competitive advantage (Webster, 1992; Zeithaml, Berry and Parasuraman, 1996). Accordingly, Timothy et-al (2007) observed that satisfied customers tend to be loyal, with less sensitivity to price changes and less attention to competition advertising. Stun and Thiery (1991) in their assertion maintain that satisfaction influences repurchased intention and satisfied customers are likely to be retained. Reichheld (1996), on his part agrees to some extent but disagree with the assumption that satisfaction is always a good predictor of customers retention, because most unsatisfied customers may choose to continue their patronage for fear of not seeing better alternative elsewhere. This assertion was corroborated by Kordic (1988), whose study of customers repeat purchase behaviour in car buying, found out that 15 percent of unsatisfied customers who defected, returned to the same dealer despite their dissatisfaction.

Satisfied customers portray favourable disposition towards the organization and are always more committed and loyal (Sullivan, 1993; Fornell, 1992; David, Soni \& Keeffee, 1995). Hence, customers' retention researches have shown that organizations will benefit from retaining their existing customers, which is cheaper to keep than to recruit new ones (Churchill and Supranant, 1982).

Dawkins and Reichheld (1990) highlight the benefits of organizational commitment to retention and maintain that higher retention rate will normally lead to higher net present value of customers. Zeithaml, Berry and Parasurannan (1996) offered a conceptual model of service quality on the behavioural pattern that signals whether customers will remain with or defect from the organization. According to them, superior service quality leads to favourable behavioural intentions that often would results in stronger customer relationship with the firm. Thus, financial rewards, increased customer spending, increased referrals, premium price and brand awareness are the pivotal benefits to be experienced by the firm. However, inferior customer service quality leads to unfavourable behavioural intentions that can weaken relationship and consequently customer defection. Such customer dissatisfaction is likely to damage corporate reputation and increase costs of business in terms of lost customers and the cost of attracting new ones. Therefore, determinants of customers' retention, according to researchers like; Reichheld and Sasser (1990); Zeithaml et-al (1996); Ranarweera, Prabhu, and Jaideep (2003) and David et-al (1995) include; sophisticated customer service, ambience business environment, wide and assorted variety of 
goods and services mix, pleasant interior, spacious layout, quality branded products as well as provision for as inspirational life style facilities among others.

Bolton and Drew (1991) observed that perceived values are influenced in part by differences in cost, customer tastes and preferences and service characteristics. Crosby, Evans and Cowles (1990) on the other hand maintained that features such as relationship quality, existence of product warranty and disposable income all affect customers' perceived value. Thus, the interaction between the customers and these factors would severely impact customer's perceived value.

Ramesh (2010) in his study of retail mix within the Indian context highlighted some important success factors in retaining customers to include: physical facilities (including corporate architecture), appropriate pricing strategies, unique promotional campaign, superior services such as prompt and courteous services, quality assurance, money back guarantee, free home services, grant and offer of credit, offer of expert advice to customers, comfort and convenience. Telang, Nishad, Sahu, Harded and Gupta (2007) on their part, identified; convenience, enjoyment and price as the three most important factors consumers consider in choosing business organizations.

Pramaik, Prankish and Prankish (2010), in their empirical study on customer retention strategies of retail shoppers, identified that retailers are practicing the following retention strategies: personal touch; such as offering seats, tea, coffee, cold drinks, initiating conversation, exhibiting welfare concerns, offering chocolate to kids and offering personal help on personal ground; communication, such as sending seasonal greeting on festivities, birthdays, marriage anniversaries, etc. informing through pamphlets, text messages, and offering information on new arrivals and clearance sales; special treatment and reward, such as monetary and non-monetary rewards and offers, including status sensitivity.

Therefore, the concept of customers' retention strategy within the context of micro- finance banks can be seen against this back drop. Judging from these empirical and theoretical evidences by scholars, Umorok (2009) concluded in his thesis that satisfied customers would not only continue their patronage, but would keep on referring prospects to the firm. Such continuous patronage lowers the retention elasticity of the firm (Oyenihi and Abiodun, 1997), grows the relationship and instils more confidence and leads to more loyalty and referrals.

\subsection{Services Variable Mix}

Consumers use basically the same criteria when evaluating services. These criteria are seen to fall into 10 categories which are labelled service quality determinants as outlined by Parasuraman and Zeithaml (1982). They include: (i) reliability- which involves consistency of performance and dependability. This suggests that the firm had performed the service right the first time. (ii) Responsiveness- refers to the willingness or the readiness of employees to provide the service and include timeliness of service, calling the customer, giving prompt attention to service etc. (iii) Competence- this is the possession of the needed skills and knowledge in performing the service. (iv) Access- involves ease of contact or convenience; Of service and include; the time the customer is waiting to receive the service, convenient hours of operation, convent locations of service facility etc. (v) Courtesy- This includes politeness, respect, consideration, and friendliness of contact personnel, including their cleanliness, neatness and smartness. (vi) Communication- is keeping customers informed. It involves such details as explaining the service to them, explaining how much the service will cost, explaining the trade off and assuring the customer that his problem will be rightly handled. (Vii) Credibility- involves trust - worthiness, believability, honesty etc. (viii) Security - is the latitude of freedom from danger a customer enjoys by avoiding risks and doubtful situations. This also includes personal safety, financial security and confidentiality. (ix) Understanding / knowing the customers involves understanding the customers' needs, wants and preferences, learning about their specific requirements, providing individualized attention and recognizing the regular customer. (x) Tangibles include physical evidence of the service in terms of physical facilities, appearance of personnel, tools and equipments used in providing the service, other customers in the service facility, etc.

\section{Methodology}

The study was conducted in Akwa Ibom State of Nigeria. Thirteen licensed micro finance banks in Akwa Ibom Sate were used in the survey. To capture the target respondents, ten copies of the questionnaire were assigned to each bank for customers to fill and return. Of the 130 copies administered, 90 were correctly filled and returned within two weeks interval. In order to arrive at the various research constructs, series of questions were raised, and all the questions were based on relevant literature. In order to ensure the reliability of the instrument, a pilot test was conducted using some banks outside the scope of this study. Through a test retest reliability measure, the obtained reliability coefficient was 0.82 or 82 percent, using Cronbachi reliability alpha. Descriptive statistics such as means and frequency distribution were used to describe the demographic characteristics of respondents. Regression analysis was used to determine factors that most likely predict retention behaviour by customers. Thus, 
multiple regression model was fitted to test how the dependent variable (customer retention) is explained by some independent variables. The functional form of the regression model can be implicitly stated as follows:

$$
Y=F\left(X_{1}, X_{2}, X_{3}, X_{4}, X_{5}, X_{6}, X_{7}\right)+e .
$$

Where $\quad \mathrm{Y}=$ customers Retention

$\mathrm{X}_{1}=$ Service Tangibles

$\mathrm{X}_{2}=$ Security

$\mathrm{X}_{3}=$ Transaction bureaucracy

$\mathrm{X}_{4}=$ Credibility/ reliability

$\mathrm{X}_{5}=$ Waiting time

$\mathrm{X}_{6}=$ communication

$\mathrm{X}_{7}=$ Knowledge of the customer

$\mathrm{e}=$ Error term.

\section{Results and Discussion}

This section presents the results and discussion of the study. The first sub-section is devoted to demographic characteristics of respondents while the other sub-section is devoted to the effect of the independent variables on customer's retention.

Table 1 showed that most of the respondents $(28.9 \%)$ are less than 30 years. This could be regarded as middle age. Only $25.6 \%$ were younger, while about $11.1 \%$ could be regarded as fairly old. i.e. 60 years and above. About 4.44 percent of the respondents did not have any form of education (Table 1). In essence, a good majority of them 96.56 percent have one form of education or the other. Moreover, Table 1 further revealed that majority of the respondents (63.33\%) were males, while only (36.67\%) were females. Table 1 also indicated that about 57.8 percent of the respondents in the study area were married. Only about 33.3 percent were single and 8.9 precent were separated.

Table 1. Demographic characteristics of respondents in the study area

\begin{tabular}{llll}
\hline S/N & CHARACTERISTICS & FREQUENCY & PERCENTAGE (\%) \\
\hline 1 & Age & & \\
& Loss than 30 & 23 & 23.6 \\
$30-39$ & 26 & 28.9 \\
& $40-49$ & 18 & 20.0 \\
& $13-59$ & 10 & 14.4 \\
& 60 and above & $\mathbf{9 0}$ & 11.1 \\
& Total & 4 & $\mathbf{1 0 0}$ \\
& EDUCATION & 20 & 4.44 \\
No formal Education & 21 & 22.23 \\
Primary & 45 & 23.33 \\
& Secondary & $\mathbf{9 0}$ & 50.00 \\
& Tertiary & & $\mathbf{1 0 0}$ \\
& Total & & \\
& GENIES & 57 & 63.33 \\
& MALE & 33 & 36.67 \\
& FEMAL & $\mathbf{9 0}$ & $\mathbf{1 0 0}$ \\
& Total & & 57.8 \\
& Marital status & 52 & 33.3 \\
& Married & 30 & 8.9 \\
& Single & 8 & $\mathbf{1 0 0}$ \\
\hline
\end{tabular}


Factors affecting customers' retention with the micro finance banks in the study area were determined using a regression analysis. This was determined from the regression results. The double log form of the equation was selected for analysis based on the R-square value. The regression results in table 2 shows a high R-square value of 0.833 or 83 percent. This implies a strong relationship between the amount of retention and the independent variables.

$$
Y=9880.231+8.216\left(X_{1}\right)+14.120\left(X_{2}\right)-744.678\left(X_{3}\right)+0.441\left(X_{4}\right)-98.857\left(X_{5}\right)+11.314\left(X_{6}\right)+0.293\left(X_{7}\right)
$$

Table 2. Results of regression analysis (double log forms)

\begin{tabular}{llllll}
\hline Variables & & $\mathrm{B}$ & Std. error & $\mathrm{t}$ & sig \\
\hline Constant & & 9880.231 & 2630.095 & 3.757 & 0.000 \\
Tangibles $\quad\left(\mathrm{X}_{1}\right)$ & & 8.216 & 4.984 & 1.648 & 0.103 \\
Security $\quad\left(\mathrm{X}_{2}\right)$ & & 14.120 & 6.030 & 2.342 & 0.022 \\
Transaction Bureaucracy & $\left(\mathrm{X}_{3}\right)$ & -744.678 & 851.261 & -0.875 & 0.348 \\
Credibility/ Reliability & $\left(\mathrm{X}_{4}\right)$ & 0.441 & 0.069 & 6.378 & 0.000 \\
Waiting Time $\left(\mathrm{X}_{5}\right)$ & & -98.857 & 71.387 & -1.385 & 0.170 \\
Communication $\left(\mathrm{X}_{6}\right)$ & & 11.314 & 29.577 & 0.383 & 0.703 \\
Knowledge of the customer & 0.293 & 0.059 & 4.956 & 0.000 \\
$\left(\mathrm{X}_{7}\right)$ & & & & \\
$\mathrm{R}^{2}=0.833$ & & & & \\
F-ratio $=58.440$ & & & & & \\
\hline
\end{tabular}

Source: Field Survey, 2010

The Table further indicates that security, credibility / reliability and knowledge of the customers were significant at the 5 percent level of probability. This shows that the independent variables of service tangibles, communication, knowledge of the customers, credibility / reliability and security all have positive relationship with the level of customers' retention. This indicates that as the employment of these factors increases, everything being equal, customers' retention will also increase. But other variables like transaction bureaucracy and waiting time had negative relationship with the independent variable. This implies that if transaction bureaucracy and waiting time increase, then customers' retention will decrease everything being equal.

\subsection{Discussions}

Remarkably consistent pattern have emerged from the empirical result of the various independent variables. Perhaps the most important insight obtained from the analysis is that a set of key discrepancies exists regarding customers' perception of service variables and the way the service is delivered to the customers. These gaps can be the major hurdle towards retention. In essence, micro finance banks may not always understand what drives customers' retention in their banks, what features a service or banks must have in order to meet customers' needs and what levels of performance or expectations on these features are needed to deliver and meet customers' expectations. This insight is consistent with previous researches in service delivery; which suggest that service marketers may not always understand what consumers expect in a service (Langeard, John, Bateson and Peoria,1981; Parasuraman, Zeithaml and Berry, 1988; Dawkins and Reichheld, 1990; Fornell, 1992; Neith, 2001; Webster, 1992).

This lack of basic understanding may affect service perception by consumers and have an overall impact on the consumers' evaluation of service, which in turn may affect satisfaction, which invariably will also affect retention (Robson, 2002; Kordic, 1988 and Koy,2003). However, the negative coefficient for transaction bureaucracy $\left(\mathrm{X}_{3}\right)$ and customers waiting time $\left(\mathrm{X}_{5}\right)$ are indicators of dissatisfaction. This has been corroborated by researchers including Oliver (1980) and Koy (2003) who in their respective studies concluded that customers want efficient services.

\section{Summary, Conclusion and Recommendations}

This study has offered several insights and propositions concerning consumers' retention in micro finance banks. The study pinpointed some key areas on the banks side that are likely to affect customers' retention as perceived by consumers. The major insights gained from this research is that a conceptual service quality model for micro finance banks will hopefully spawn both academic and managerial interest and serve as a framework for further empirical research in this growing important sector. Based on the above, we conclude as follows: 
(a) That the key problems of customers' retention strategies are influenced by a series of distinct gaps often neglected by the firm. Therefore, a key challenge for micro finance banks and scholars in this field is to device methods to measure these gaps accurately in the market.

(b) Secondly, that although some variables exhibit negative associations, further research is needed to examine the nature of the association between customers' retention and its determinants.

(c) Thirdly, the usefulness of segmenting consumers on the basis of their expectations is worth exploring its possibilities with the micro finance banks

Based on the above conclusions we recommend a three-fold retention strategy for the micro finance banks:

(i) It is important that the concept of patronage behaviour, customer satisfaction, relationship marketing, customer loyalty and retention be considered in the context of micro finance bank's geo-demographic, socio-economic and other environmental contexts with a view of utilizing their opinions on satisfaction survey in improving retention and business performance.

(ii) Micro finance banks need a solid foundation for creating customer loyalty, which includes; reducing churn drivers through proactive and reactive retention measures, while also creating loyalty bonds such as giving loyalty rewards in the form of financial, non - financial, higher tier service levels, recognition and appreciation.

(iii) Finally, it is also recommended that micro finance bank should attempt to segment their market to match customer needs and firm capabilities by managing customer base via effective tie ring of service delivery of quality services as well as conducting churn diagnostic monitoring of declining/ defecting customers

\section{References}

Andersen, E. W., Fornell, C., \& Lehmann, D. R. (1994). Customer Satisfaction, Market share and Profitability: Findings from Sweden. Journal of Marketing, 58, 53-66. http://dx.doi.org/10.2307/1252310

Anderson, E. N., \& Sullivan, M. W. (1998). The Antecedents and Consequences of Consumer Satisfaction for Firms. Marketing Science, 12(2), 125-143. http://dx.doi.org/10.1287/mksc.12.2.125

Churchill, G. A., \& Suprenant, C. (1982). An Investigation into the Determinants of Customer Satisfaction. Journal of marketing Research, 19, November, 419-504.

Crossby, L. A., Evans, K. R., \& Cowles, D. (1990). Relationship Quality in Service Selling: An Impersonal Influence Perspective. Journal of marketing, 54.

David, W. T., Soni P. K., \& Keeffee, M. (1995). Modeling Customer Retention as a Relationship Problem. ISBM Report 134995, The Pennsylvania State University.

Dawkins, P. M., \& Reichheld, F. F. (1990). Customer Retention as a Competitive Weapon, Directors and Board, Sumer, 42.

Fornell, C. (1992). A national customer satisfaction barometer: the Swedish experience. Journal of Marketing, 6. http://dx.doi.org/10.2307/1252129

Jones, T. O., \& Earl, W. (1995). Why Satisfied Customers Defect. Harvard Business Review, 73(6), 88 - 99.

Kordick, J. A. (1988). Doing well by doing good. In Ford parts and service Division (Eds.), International Documentation of the Ford Motor Company. Presentation at the $13^{\text {th }}$ Automotive News world congress in Detroit.

Koy, B. P. (2003). An Examination of the Relationship Between Service Quality, Customer Satisfaction and Store Loyalty. International Journal of Retail and Distribution, 28(2), 73 - 92.

Langeard, E., John, E. G., Bateson, C. H., \& Peoria, B. (1981). Service Marketing: New Insights from Consents and Mangers, Caboodle. MA: Marketing Service Institute.

Neth, P. D. J. (2001). Customer Relationship Management: Emerging Practice, Processes and Discipline. Journal of Economic and social Research, 3(2), 1-34.

Oliver, R. L. (1980). A Cognitive Model of the Antecedents and Consequences of Satisfaction Decisions. Journal of Marketing Research, 4, 460. http://dx.doi.org/10.2307/3150499

Oyenihi, O., \& Abiodun, A. (2008). Customer Service in the Retention of Mobile Phone Users in Nigeria. J. Bus. Management, 2(2), $26-31$.

Palmer, A. (2002). The Evolution of an Idea: An Environmental Explanation of relationship Marketing. Journal of Relationship Marketing, 1, 79 - 94. http://dx.doi.org/10.1300/J366v01n01_06 
Parasuraman, A., Zeithaml, V. A., \& Berry, L. L. (1988). SERVAQUAL: A Multiple Item scale for Measuring Customer Perceptions of Service Quality. Journal of Retailing, 64(1).

Premark, R., Prankish, S., \& Prankish, G. (2010). Empirical Study of Customer Retention Strategies of Small Retail Shoppers. Journal of Business and Retail Management Research, 4(2).

Rabson, C. (2003). Real would Research (2nd ed.). London: Blackwell Publisher.

Ramesh, H. N. (2010). Retail Mix Managements Synoptic View. Journal of Business and Retail management Research, 4(2).

Ranaweera, C., \& Prabhu Jaideep. (2003). The Influence of Satisfaction. Trust, and Switching Barracks on Customer Retention in a Continuous Purchasing Setting. International Journal of service Industry management, 14(4), 374 - 395. http://dx.doi.org/10.1108/09564230310489231

Reichheld, F. F. (1996). Learning From Customer Defections. Harvard Business Review, 74(2), 56 - 69.

Reichheld, F. F., \& Kenny, D. W. (1990). The Hidden Advantages of Customer Retention. J. Retail Bank, 12(4), $19-23$.

Reichheld, F. F., \& Sasser, W. E. (1990). Zero Defections: Quality comes to Services. Harvard Business Review, Sept -Oct, 105.

Stun, T., \& Thiry, S. (1991). Building Customer Loyalty, Train. Dec. Journal of Marketing, 34 - 36.

Sullivan, S. B. (1993). Management of Service Operations: Text and Cases. Boston: Allyn and Bacon.

Telang, V., Nishad, S., Sahu, L., Harded, P. N., \& Gupta, S. (2007). Retailing Strategies for Organized Retailers in Indian Sub - urban Markets. Proceedings of the National Conference on Strategies for Creating Effective Global Organization - Technovision 2007. Shri Sharikaracharya Institute of Management and Technology, Bhilad, India.

Timothy, L., Bruce, K., Larzan, A. T., \& Jao, W. (2007). The Value of Different Customer Satisfaction and Legality Matrices in Predicting Customer Retention, Recommendation and Share of Wallet. Journal of Service Quarterly, 17(4), 361 - 384.

Webster, F. (1992). The Changing Role of Marketing in the Corporation. Journal of Marketing, Oct., 1 - 17. http://dx.doi.org/10.2307/1251983

Zeithaml, V. A., Berry, L. L., \& Parasuraman, A. (1996). The Behavioral Consequences of Service Quality. Journal of Marketing, 60, 3. http://dx.doi.org/10.2307/1251929 